\title{
IMPLEMENTATION OF DEVELOPMENTAL TOPICS INTO UNIVERSITY EDUCATION
}

\author{
Eva Svitacova - Elena Kovacikova
}

\author{
doi: 10.18355/PG.2016.5.1.162-173
}

\begin{abstract}
Globalization changes the direction of the university education and influences structural changes in the content of the curriculum. As universities try to prepare graduates for practice within new global environment, this paper points towards the need to implement global education and some educational approaches, including development education into the university education. Thus, the development topics can be implemented into the curriculum of universities. This paper interprets the reasons for implementation of such topics into university studies, and introduces several research projects realized at the Slovak universities.
\end{abstract}

\section{Key words}

university study, implementation, new educational approaches, global education, development topics, globalization

Development of a country depends mostly on its people, their knowledge and creativity potential which means that the educational system should be adapted to the needs and requirements of the current world. As it should provide the education of global citizens who shall become active citizens of the Earth and qualified professionals in particular professions and field of life at the same time, there is a strong need for implementation new knowledge from particular fields of research, as well as actual knowledge about situations in the world, social processes and phenomena, problems and risks appearing in a new global environment. Due to the fact that in a global world, the human capital is forced to be constantly adapted to new conditions, it needs to solve new demands on qualifications and fulfil the fund of professional knowledge within the whole human life, it is necessary to pay attention to its preparation, formation and also to its use in university education. Globalization substantially changes the direction of university studies. A necessary condition is internationalization in order to provide a long-term competitiveness of higher educational schools and universities on a global, European and national level. Its task is to strengthen European dimension of education and broaden knowledge and cultural view of future graduates about the knowledge connected with the need to respect social and political realia of not only European countries but the whole world.

In connection with European university studies, the document of European Commission (2013) states that the complex strategy of internationalization should cover key fields divided into three categories: international student and employee motilities; internationalization and quality improvement in study programs and digital education; strategic cooperation, partnerships and building capacities. These categories should not be perceived 
separately however, as integrated parts of the complex strategy. Slovak universities also pay attention to the quality improvement of study programs by the means of internationalization as they realize the need to be flexible due to the new requirements of the new global environment in order to be more competitive. Their task is to compete with other universities in an open European space in a way that they strive to improve quality of graduated as for example with creating appropriate content of particular study programs.

Each strategy of internationalization should prove the basic values of European culture (protection of human rights, cultural heritage of societies, support of social coherence) and the development of cooperation with developing countries which should be based on innovative models of partnership strengthening the cooperation North-South and South-South (European Commission, 2013).

J. Benyak et al. (2014) state that due to this strategy, it is necessary to develop such study programs at Slovak universities as well. More intensive internationalization of economic life influences changes in the structure and content of educational system in particular countries. Economic globalization has different influences in education and also in curriculum.

V. Mezricky (2011) assumes that on a tertiary level of education it is necessary to implement not only the most current research findings from a particular filed, but also development topics due to which the students get an overview on global situations, social inequalities, risks and global problems. The impulse for implementation of developmental topics into education is undoubtedly the process of globalization which represents the global integration of political, economic and cultural processes. J. Benyak et al. (2014) also assume the globalization to be an essential term nowadays discussed in a field of comparative pedagogy.

P. Ondrejkovic (2011) comments that higher educational schools and universities should focus on development of study plans in a way that through educational process students will acquire such knowledge, skills and altitudes which help them realize their future practice in any part of the world. Education changes not only qualification potential of a person but it also forms and cultivates the human personality, their overall cultural level. The human capital bears universal human skills, helping to make statements, eliminate or limit the risks and negative phenomena in every field of a human activity. Due to implementation of development topics into university education, the social capital of the graduates acquiring competences is formed. Thus, they easily integrate into the society, realize their practice in any part of the world.

\section{Requirements for university study in a new global environment and new educational approaches}

Actual demands of current employers in the world apparently do not cover only professional skills and competences of specific character but most of them take for granted that their employees can adapt to any conditions in a new global economic and social environment and there with any problems

Slavonic Pedagogical Studies Journal, ISSN 1339-866o, Volume 5 Issue 1, February 2016 
they are able to realize their tasks. Human capital is constantly in a new global environment, it is constantly forced to adapt to new conditions, succeed in new demands for their further qualification, etc. Due to this fact it is extremely important to pay attention to its preparation and formation. Education altogether with innovation, science and technologies, entrepreneurships are considered to be real engines and key priorities of competitiveness. The competitive development of global economy depends on educational system to the great amount, as well as on human quality of life in particular countries. Education at universities should participate in development of a human qualification potential and besides that also on formation and cultivation of a human personality, the cultural level, based on which the people are able to be implemented into different social institutions in the world and follow demanding tasks. The education can enable integration to the society and help gaining for example better working places, higher income, higher social status, etc.

New global environment represents qualitatively a new level of economic life internationalization and it connects with new demands on human capital. We cannot doubt the possibilities which have been brought by this new environment, but also the problems and risks piling there, too. Regarding the fact that it is necessary to prevent negative phenomena and effects on human lives in the world, and also on the nature, the young generation becomes the hope. And it is necessary to prepare this generation for the life in a globalizing world. That is an attempt of the educational institutions at all the levels. Higher secondary schools and universities realize their tasks and therefore they strive to prepare their graduates for their practice which might be realized not only in national organizations and institutions but also in the global economic structures, in different organization in the world. They are based on the fact that except of the knowledge and experience from the studies at home and abroad, essential language preparation, their graduates will need also the knowledge which will help them adapt in a new global economic and social environment and fulfil the demanding tasks. In the education process they pay their attention towards formation of social competences thanks to which the university graduates will be able to cope with several phenomena, changes in the current globalizing world and cooperate together with different subjects.

DeSeCo (Definition and Selection of Competencies) and majority o OECD countries implemented social competences among nine key competences, which represent abilities to create mutually prosperous and constructive relations with others and they are key ones for stimulation of cooperation. Social competences are undoubtedly important for university graduates, i.e. highly professional experts who will realize their practice in a new global environment. Thanks to them they are able to enter into the complex of the global problems and examine connections between their lives and people, places or problems around the world.

Different authors - teachers, psychologists and sociologists focus on development of social competences and they suggest several methods of their formation (training of social skills, a training of social competence, development of personal potential, etc. The above mentioned methods have 
been used mainly in primary and secondary education and some of them have started to be used also at universities, as for example within the global education.

Global education becomes an actual form of education in a modern society which helps forming social competences of pupils and learners at all levels of schools. Global education is considered to be the "progressively developing educational approach supporting comprehension and cooperation among people. It involves learning about problems and phenomena overcoming the borders of the countries which are of a global nature. These are mainly ecological, cultural, economic, political and technical problems. Global education emphasizes perspectives, needs and visions of perceiving and understanding problems from different points of views, cooperative learning, critical thinking and responsible action respecting intercultural, ethnical, national, regional, local, group and individual differences. The global education represents a new stream in education which has now a nature of a movement. It is mostly realized at secondary and higher secondary schools and in the form of practical activities, cross-curricular topics and complex projects."(Prucha, Walterova, Mares, 2008: 69).

G. Pike and D. Selby (1994) understand the global upbringing as a direction interconnecting reflections of global problems of the Earth (planetary consciences), pedocentrism (emphasis on a central status of a child in an educational process) and system theory (focus on relations among elements). "The aim of the global upbringing is generally a development of global knowledge of learners and their preparation for lives in the global world." (Svitacova et al, 2014: 70). Global upbringing is a philosophical framework and a practical way of education for the democratic society and sustainable future. Global education is its part which focuses on a global context in teaching and learning. Within the classification of the current directions of pedagogical thinking the global upbringing might be implemented in the group of social theories of education with the idea that transformation of schools has a broader social dimension and the main objective of education is a change, reconstruction of the society. Global education is a part of it which focuses on a global context in teaching and learning. Maastrict Declaration of Global Education was approved in 2002 and it has become an important document covering global education. This declaration published a definition of the global education issued by the North South Centre Council of Europe (NSC).

Global education is a process in which didactic aspects come first. From this point of view it focuses on mediating the educational content with the aim to develop knowledge from the field of the global problematics. "Through global education the increase of global topic awareness related to every individual towards the critical thinking within these topics and deeper comprehension of the fields and topics relating to the whole world." (National strategy for Global Education for 2012 - 2016: 1)

The National strategy explicitly states that the global education is perceived as a covering principle. Global development education is a part of it

Slavonic Pedagogical Studies Journal, ISSN 1339-866o, Volume 5 Issue 1, February 2016 
(education on problems of third world countries and global poverty), environmental, multicultural, peace education as well as education towards the human rights under the global context (Ibid.)

Implementation of modern educational conceptions, based on actual trends in the society as well as from the modern knowledge of the pedagogical theory into the process of the university study are considered to be an effective instrument of the support of university quality. One of the modern educational approaches is also a development education or development studies. R. Malachovsky (2011) states that in case of non-pedagogical universities, the term development studies are suggested. The general aim of founding development studies in Slovakia is a preparation of future development workers, so-called practitioners, who are due to crosscurricular focus of such a study program, able to apply in political, economic and socially focused professions.

E. Taldikova (2011) states the above mentioned terms have been naturalized in the academic field in western countries. They put a stronger focus on problems of development support of developing countries rather than the terms like global education and global development education. For R. Malachovsky (2011) development education should develop skills enabling perceiving the world more attentively in which we live and it provides us with values leading towards cooperation and acquiring sustainable development in the world. E. Mistrik (2014:19) states that it is "education towards noticing global problems and responsibility for the global development of the human kind." J. Hips and P. Durisova (2006) introduce its aim as gradual implementation of global and European dimension into the process of upbringing and education. It focuses on the "clarification of connections between global happenings and developing countries and it represents an excellent and interesting addition to the content of various subjects or afterschool activities. Development education supports an active participation of all citizens in their global attempt to remove poverty and disadvantaging.

The aim of the global upbringing through the above mentioned approaches (global education, global development education or development education) is to strengthen the feeling of belonging towards the global society and adequate introduction of global challenges, but also problems, risks or threats in the world. At the same time, for J. Lysy (2007: 88) the aim is to lead citizens towards understanding that the world is interconnected by the systems of cultures and activities and local decisions influence it and vice versa, the local decisions are affected by the global problems.

One of the aims of global upbringing is to grow pupils and students to become global citizens. Future universities should be transnational and educate global citizens and they are expected to be interested in various questions and problems in the global space related to all citizens in the world. "Global citizenship thus represents an idea that human kind creates one big society which should be based on understanding, solidarity, cooperation and mutual support and we as global citizens shall be able to accept responsibility for the development and direction of this society" (Svitacova et al, 2014: 50). Education towards global citizenship is 
equally important at universities. Its task is to provide students with knowledge, skills and approaches in order to understand the rights and obligations they have as global citizens. Thanks to this they should acquire a positive approach towards citizenship and become active and responsible members of the society not only on a national but also transnational global level.

\section{Development topics in university education}

Qualifications and Curriculum Authority (2010) introduce several reasons for implementation of development topics into university education. First of all, they reveal a global dimension which focuses on the research of such facts which connect us with the rest of the world. Mainly through education thus students are able to get to the complex of the global problems and search for connections between their own lives and other people, places or problems around the world. The global dimension touches developing but also developed countries. It helps students develop their images of different forms of their future as well as tasks they can take in a new fair and sustainable world.

Except the fact that development topics reveal the global dimension to students, they inform them about a situation in the world, help them realize their position in a globalizing world and also tasks they have as global citizens. It is possible to state also other reasons for implementation development topics into university education. They relate to the future practice of university graduates in a new global environment. We assume that will take mainly leading functions in which they will have to cope with cultural peculiarities and other problems not only in the organization but also in the wider environment. As for example, it is expected that by fulfilling professional and working tasks they will encounter global problems, risks and threats, but also they will have to make statements on different processes in the world such as migration, poverty, multiculturalism, terrorism, etc. Thanks to implementation of development topics into educational process at universities, students can gain valuable information on actual happenings, processes and situations in different parts of the world. Furthermore, it is assumed that they can realize their responsibility in their tasks in the society and at the same time, share responsibility for economic, political, social and cultural development of the world as for the sustainability of natural environment in a local and global level.

The National strategy for global education (2012-2016) deems students and academic employees to be one of the target groups of the global university education. Its main aim is "to provide the target groups with information enabling comprehension of social, environmental, economic and political processes in the world develop critical thinking and form global attitudes." (National Strategy for Global Education for 2012 - 2016: 7). Regarding this aim, university education shall cover also main topics of global education (globalization and mutual interconnection, global problems and 
development cooperation, multiculturalism, environment regarding the global aspects, and human rights.

Besides that, particular universities can implement further topics into their curriculum regarding the specialization and focus of particular faculties and universities (Implementation of development topics in curriculum is not mandatory. Development education is possible to be realized also by other forms). As for example, graduates of economic faculties and universities are expected to realize the complex nature of the current world, i.e. mutual interconnection of the nature, culture, technologies and economy as well as connection of particular regions as well as mutual interdependence of developed and developing countries, etc. Besides gaining professional knowledge from the field of economy, management and marketing, it is more than important to get more complex knowledge on situations in a new global environment, processes and phenomena, but also about problems occurring there.

In the research focusing on implementation of global development education in the education process at economic faculties (under KEGA No. 006SPU-4/2012), running in 2012 - 2014, teachers from departments of social sciences from several economic faculties through their workshops pointed mainly at the fact that many students lack the ability to see the things in relations. Social phenomena and processes altogether with economic ones are perceived by them separately. However, these topic and problems covered by global development education are more or less implemented in all the subjects taught by these departments. Except of this fact, the study plans contain also other subjects/courses in which the global and development problematics are involved. Based on this fact, the workshop participants agreed with the need of systematic implementation of development topics into education at economic faculties and universities. Development topics should contribute and develop some knowledge which was acquired in the professional subjects. As for example, reveal the reversed side of economic globalization and point at some processes in the new global environment accompanying globalization and human lives. These are topics which can be implemented in the four main fields: political, social, economic, and environmental. These fields correspond with the main aim of the global education, structured by the National Strategy for Global Education for 2012 - 2016 which says that "the main aim is to provide the target groups with information enabling understanding the social, environmental, economic and political processes in the world, develop critical thinking and form the global attitudes in citizenship."

Partners of the project agreed that $\mathrm{i}$ tis appropriate to implement the following topics: Origin and tendencies of globalization development (technical, economic, social factors and political connections of globalization), effect of globalization on changes in the system of international relations. Further on the topics: Applying human and social rights - significant condition of humane realization of the current globalization, Democracy and society and last but not least, the topic of Global citizenship. The social field should be enriched with topics such as: 
Multiculturalism, Cultural identity, Differences and intercultural communication, Migration, Population problems.

Extremely important is an economic field where i tis appropriate to implement topics such as: Social responsibility of entrepreneurship in a new global economic environment, Infrastructure and economic development in developed and developing countries of the world, etc.

Environmental problems are equally important for students of economic faculties and universities. As for illustration: Global problems of environmental nature, Energetic problem, its performance and solutions; Global contributions of energetic use of biomass, Biogas stations in developing countries, Technics and technology in the era of globalization.

Several topics which should the global development education contain at economic faculties are implemented in the content of a new university textbook Global development education for economists which is primarily aimed for students of economic universities and faculties but also to economists in the practice..

Nowadays, other projects have been working on the implementation of the global development topics into the tertiary education and the project coordinators are the university teachers. As for example projects Global education at the Faculty of Ecology and Environmental Sciences and Global Education in Connections have been running at the Faculty of Ecology and Environmental Studies at the Technical University in Zvolen. The project of the Centre of the environmental study and ethical education Živica and Technical University in Zvolen was supported by the Slovak Aid within the call No SAMRS/2013/ - Development Education, the capacity building and co-financing of projects approved by the European Commission under the National Program of the Official Development Support of the Slovak Republic for 2013.

The main aim of the other project - Global Education in connections is to create conditions for implementation of development topics in the study programs at the university level. (Project CEEV Živica, approved within the grant of the Slovak Aid). In order to follow this aim, an international research was realized with 300 students of the Technical University which was carried out in cooperation with Professor Vanessa de Oliveira Andreotti from the University in British Columbia, Canada. The international methodology of research was applied on 20 foreign universities and the Technical University in Zvolen was the only one joining the research form all the middle and east Europe (Zaludko, 2015). In real, there was an innovation of 5 subjects in minimum at 3 faculties and one university program Management and Financing of forest enterprises at the Technical University in Zvolen. Into all of the above mentioned, the development topics were implemented.

Implementation of development topics into university education can be considered to be an important step towards labelling Slovak universities as "global universities." The proof of this is an initiative project: Global university III: Implementation of development topics into the system of university education, which is realized under the SlovakAid scheme in

Slavonic Pedagogical Studies Journal, ISSN 1339-866o, Volume 5 Issue 1, February 2016 
which the Pontis Foundation is a coordinator. The main objective of the project is to create conditions for implementation of development topics into study programs at non-philological universities. The specific aims of this project focus on the support of development education at the Slovak University of Agriculture in Nitra and at the Faculty of Art at the Comenius University in Bratislava (the Department of ethnology and music studies) and for preparation of professional capacities for further institutionalization of development studies at Slovak university of agriculture in Nitra. Last but not least, the aim of the project is to rise more active interest of students about the topics in development education.

Four educational programs of life-long education were developed which focus on development topics (Sustainable agriculture in rural development, International Relations and Globalizations, International business, Regional Development and Marketing (for more information see the project and events at the Slovak University of Agriculture in Nitra). Under auspices of the Life-long learning education Office coordinated by the Rector's office of the Slovak University of Agriculture a piloting course Development education for students of Master and $\mathrm{PhD}$ programs, consisting of four accredited programs. Its realization was carried out in four parts involving actual development topics. After finishing the piloting course the graduates were given the Certificates on Attendance in Accredited Educational Lifelong Learning Programs. Educational materials and university textbook - Development Education were developed for students' support as well as Topics and methods II for the purposes of further education of development education at the Slovak University of Agriculture and the Faculty of Arts at the Comenius University. We can thus state that both universities are provided with relevant literature about development studies. It can be assumed that these materials will serve as a base for further institutionalization of development education at the Slovak University of Agriculture in Nitra and via accreditation at the Ministry of Education of the Slovak Republic.

One of the project contribution are also new voluntary and guest lectures related to topics from development education for students of the universities joined to this research project. The guest lectures are realized by the teachers from the universities which are the partners of the project. Last but not least, some researchers have been provided with the possibility of stays at some professional institutions abroad, they gained professional experience and started deeper international cooperation. A long-term and main contribution of the project Global University III: Implementation of development topics into the system of university education is the fact that both the teachers and the students at the universities gained information from the field of development education, are more deeply engaged with the problematics and they are able to use the acquired knowledge in their practice.

\section{Conclusion}

It is more than necessary to inform students about development topics and implement new educational approaches at different faculties and 
universities in order to make university education of a higher quality. We can agree with the motto that "being educated in a current globalized world means to have an access to quality global education enabling improvements in understanding of globalizing aspects of the culture, economics, society as well as the political system - at different levels - local, regional, and global one“ (Lysy, 2007: 6). As it is obvious from this paper in Slovakia nongovernmental organizations e.g. Pontis, Zivica have been engaged in this direction for a long time. However, schools and schooling institutions as well as Slovak universities are one of the key actors of the National strategy for the global education for 2012 - 2016. Their task is to provide the students more deeply with understanding particularities and inequalities in the world. They should be able to reveal of their reasons and find solutions for many other problems which are piled in today's world. Regarding their specializations they should pay attention to particular topics, update them, add necessary information and interpret them accordingly. Moreover, applicable forms for their implementation into educational process should be found. Thanks to implementation of development topics into university education also goes hand in hand formation of professional profile of university graduates who are then able to find vacancies in different institutions and organisations in a new global environment. Implementation of development topics into educational process at Slovak universities thus becomes an effective way of increasing their competitiveness in the world.

\section{Bibliographic references}

BENYAK, J. - KOVEROVA, E. - VRANAIOVA, K. 2014. Vybrane atributy komparativnej pedagogiky ako vedneho odboru. In Pedagogika, vol. 5, n. 3, pp. 193-218.

EUROPSKA KOMISIA. 2013. Oznamenie komisie europskeho parlamentu, Rade, Europskemu hospodarskemu a socialnemu vyboru a vyboru regionov. Europske vysokoskolske vzdelavanie vo svete. Brusel.

HIPS, J. - DURISOVA, P. 2006. Svet je len jeden: prirucka globalneho rozvojoveho vzdelavania. Zilina: CEEV ZIVICA. ISBN 80-968989-5-7.

IMPLEMENTÁCIA globalneho rozvojoveho vzdelavania do edukacneho procesu na ekonomickych fakultach. Projekt c.006SPU-4/2012 Portal VS.sk Available online: https://www.portalvs.sk/ sk/prehladprojektov/kega/6713

LYSY, J., ed. 2007. Globalne rozvojove vzdelavanie. Bratislava: ALBUM. ISBN 978-80-968667-7-9.

MALACHOVSKY. R. 2010. Globalne rozvojove vzdelavanie na Slovensku. In Newaletter o rozvojovej pomoci. c.1 Nadacia Pontis. Available online: http://fzasp.truni.sk/sites/default/files/dokumenty/Newsletter_1_2011_Ponti s.pdf

MEZRICKY, V. 2011. Perspektivy globalizace. Prague: Portal 2011. ISBN 978-80-7367-846-3, p. 12 
MISTRIK, E. 2014. Zmysel a moznosti rozvojoveho vzdelavania. In Rozvojove vzdelavanie. Temy a metody. 2. vyd. Bratislava: Pontis. pp. 634. ISBN 978-80-971310-2-9.

ONDREJKOVIC, P. 2011. Socialny a kulturny kapital ako socialne hodnoty, normy a ciele vo vychove a vzdelavani. In Pedagogika, vol. 2, n. 4, p. 228-244.

PIKE, G. - SELBY, D. 1994. Globalni vychova. Praha: Grada. 322 s. ISBN 80-85623-98-6.

NARODNA STRATEGIA PRE GLOBALNE VZDELAVANIE NA OBDOBIE ROKOV 2012 - 2016. 11 p. [cit. 2016-01-20]. Available online: https://www.mzv.sk/documents/10182/68590/130325_Narodna_stretegia_g lobalne_vzdelavanie_2012_2016.pdf/d01b5991-b713-4446-a679-

d32668fba343

PROJECTS AND EVENTS. Slovenska polnohospodarska univerzita v Nitre. [online] Availabe at: www.uniag.sk/sk/projekty-a-podujatia/

PRUCHA, J. - WALTEROVA, E. - MARES, J. 2008. Pedagogicky slovnik. Prague: Portal. ISBN 978-80-7367-416-8.

SVITACOVA, E. a kol. 2014. Globalne rozvojove vzdelavanie pre ekonomov. Nitra: SPU. ISBN 978-80-552-1234-0.

SIKULA, M. 2007. Utvaranie znalostnej ekonomiky a spolocnosti ako zakladny determinant pristupu $\mathrm{k}$ vízii a strategii rozvoja slovenskej spolocnosti. In Pracovny odborny seminar Vizie a strategie rozvoja slovenskej spolocnosti. Bratislava: Institut ASA, 24. May 2007, [cit. 201512-28]. Available online: http://www.inst-asa.sk/userfiles/file/Sikula.doc

TALDIKOVA, E. 2011. Globálne (rozvojové) vzdelávanie na Slovensku doterajši vývoja perspektívy. Bratislava. [cit. 2015-12-27]. Available online: http://www.gerc-

et.info/media/uploads/gerc_net_info/analysis_of_ge_slovakia.pdf $>$.

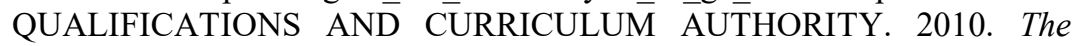
global dimension in action : a curriculum planning guide for schools. London: QCA, 48 p. [cit. 2016-01-27]. ISBN 1-84721-582-3. Available online: https:/www.gov.uk/ government/organisations/qualifications-andcurriculum-authority

ZAGORSEKOVA, M. 2012. Vplyv medzikulturnych vztahov na transformaciu socialneho a kulturneho kapitalu. In Aktualne otazky svetovej ekonomiky a politiky. Bratislava: EKONOM, pp. 543-546. ISBN 978-80225-3559-5.

ZHAO, Y. Preparing Globally Competent Teachers: A New Imperative for Teacher Education. In Journal of Teacher Education, vol. 61, n. 5, pp. 422431.ISSN 1552- 7816 doi: http://dx.doi.org/10.1177/0022487110375802.

ZALUDKO, J. 2015. Globálne vzdelávanie v súvislostiach. 23. februára 2015 Available online: http://err2015.zifer.sk/globalne-vzdelavanie-vsuvislostiach/

\section{Acknowledgement}

The paper was written under the project Global University III: Implementation of development topics in the system of university education. No. SAMRS/2014/RV/01/06. 
Mgr. Eva Svitačová, PhD.

Slovak University of Agriculture

Faculty of Economics and Management

Department of Social Sciences

Tr. Andreja Hlinku 2, 94976 Nitra, Slovakia

eva.svitacova@fem.uniag.sk

Mgr. Elena Kováčiková, PhD.

Constantine the Philosopher University in Nitra

Faculty of Education

Department of Language Pedagogy and Intercultural Studies

Drážovská 2, 94901 Nitra, Slovakia

ekovacikova@ukf.sk 